\title{
Diversifying cereal-based rotations to improve weed control. Evaluation with the AlomySrs model quantifying the effect of cropping systems on a grass weed
}

\author{
Nathalie COLBACH ${ }^{1}$ \\ Anne SCHNEIDER ${ }^{2}$ \\ Rémy BALLOT ${ }^{2}$ \\ Christophe VIVIER ${ }^{3}$ \\ 1 INRA, \\ UMR 1210 Biologie et Gestion des Adventices, \\ BP 86510, 17 rue Sully, \\ 21065 Dijon Cedex, France \\ <colbach@dijon.inra.fr> \\ ${ }^{2}$ UNIP, Union Nationale Interprofessionnelle \\ des plantes riches en Protéines, \\ 12, avenue George V, \\ 75008 Paris, France \\ ${ }^{3}$ Chambre d'Agriculture de I'Yonne, \\ 14 bis, Rue Guynemer, \\ 89015 Auxerre, France
}

\begin{abstract}
Simplified rotations often select weed flora consisting of one or several dominant species. In rotations consisting mainly of winter cereals, one of the most frequent weeds in Atlantic European countries is blackgrass (Alopecurus myosuroides Huds.). In order to reduce environmental impacts and avoid the selection of herbicide-resistant populations, alternative weed management strategies are necessary. The objective of the present study was to develop a methodology for using a weed dynamics model called ALomYSys for evaluating prospective diversified crop rotations based on expert opinion. These prospective rotations were developed for a particular region aiming at reducing herbicide use while keeping weed infestation similar to that in current cropping systems. The prospective systems were also evaluated economically by calculating costs and margins for the farmer. The simulations showed that the more diverse the rotation, the better blackgrass was controlled and the less herbicides (rates and frequencies) were necessary. Optimal herbicide spraying conditions and mouldboard ploughing were also less essential in diverse rotations. It was though essential to reason herbicide programs over the whole rotation and not simply as function of the preceding crop. The economic evaluation identified the interest of spring or winter pea either replacing or preceding oilseed rape (OSR) in OSR/wheat/barley rotations.
\end{abstract}

Key words: rotation, diversification, pea (Pisum satia L.), oilseed rape (Brassica napus L.), weeds, previous crop
One of the problems occurring in simplified rotations is the selection of a weed flora consisting of one or several dominant species that mimic the crop cycle, with seeds being least dormant when the crop is usually sown, and a post-emergent growth and development allowing reproduction before crop harvest (Fried et al., 2008; Fried et al., 2009). In rotations consisting mainly of winter cereals, one of the most frequent weeds in Atlantic European countries is Alopecurus myosuroides Huds. (blackgrass, Van Himme \& Bulcke, 1975). As this weed is increasingly tolerant to various herbicides (Moss, 1987; Gasquez, 1996; Délye et al., 2007), it can reach densities exceeding cereal densities, even after herbicide application, particularly in rotations consisting solely of winter crops (e.g. 300 plants $/ \mathrm{m}^{2}$, Chauvel et al., 2001).

Consequently, new cropping system strategies are required to manage such weeds. Moreover, because of environmental and health safety issues, it is necessary to develop strategies that do not rely on herbicides to manage weeds. Modifying, particularly diversifying rotations would appear to be a major lever to achieve this goal. Evaluating numerous rotations at long-term in experiments is though unfeasible. However, it is now well recognized that models that quantify the effects of cropping systems on weed dynamics are valuable tools to design weed management strategies (Aubertot et al.; Rossing et al., 1997). To date, the AlomySys model (Colbach et al., 2006a; 2006b; 2007) is the most complete model for blackgrass. Compared to previous blackgrass models (e.g. Doyle et al., 1986; Munier-Jolain et al., 2002), it presents the major advantage of using a mechanistic approach where the life-cycle is split into sub-processes depending on biological and physical effects of cropping systems, in interaction with the biological (e.g. weed stage) and physical conditions (e.g. soil structure). This approach is necessary to understand and predict the variability in effects observed for given cropping systems and to use these models in a large range of conditions without reparametrising (Colbach and Debaeke, 1998; Colbach et al., 2005; Colbach, 2010).

The objective of the present study was to develop a methodology for using the ALOMYSYS model for evaluating prospective diversified crop rotations based on expert opinion. These prospective rotations were developed for a particular region aiming at reducing herbicide use while keeping weed infestation similar to that in current farming systems. The prospective systems were also evaluated economically by calculating costs and margins for the farmer. This study was part of a larger project evaluating diversified rotations (Schneider and Dumans, 2010, present journal number).

\section{Material and methods}

\section{Model structure}

The structure of ALomySys is described in detail by Colbach et al. (2006a; 2006b; 2007). Only the main aspects are described here. The input variables of ALOMYSys consist of:

- the above-ground climate (daily temperature and rainfall) and the soil climate (daily temperature, soil moisture and water potential for each day and for each of the 30 soil layers ranging from 0 to $30 \mathrm{~cm}$ ). Soil climate is either measured in the field or simulated with existing models such as STICS (Brisson et al., 1998a); - a description of the simulated location (soil texture and depth); 
- the initial weed infestation (plants $\cdot \mathrm{m}^{-2}$ ); - the cropping system during the whole simulated period, comprising the crop sequence including set-aside, temporary grassland and cover crops, the date of all operations (tillage, sowing, herbicides, mechanical weeding, mowing, organic and mineral fertilizer, harvest) and their characteristics, i.e. tool, working depth, tractor speed for tillage and mechanical weeding, active ingredient, rate and conditions (good, intermediate, bad) for herbicides, seed density for sowing, nitrogen rates for fertilizer.
These input variables influence the annual lifecycle of blackgrass (table 1), in interaction with weed stages (e.g. mortality after herbicide application depends on blackgrass stage and density), crop stages (e.g. seedling survival after emergence depends on its emergence date relative to the crop emergence date) and environmental conditions (e.g. pre-emergent seedling mortality increases with the size and compaction of soil clods as well as soil dryness). All life-stages are described in output files, but the main output variables comprise daily emerging seedlings, total density of mature

Table 1. Effects of cropping system components on the blackgrass life-cycle as simulated by ALomrSys (Colbach et al., 2006b; 2007; 2010).

\begin{tabular}{|c|c|c|}
\hline $\begin{array}{l}\text { Cropping } \\
\text { system }\end{array}$ & Intermediate effect & Effect on blackgrass \\
\hline \multirow{5}{*}{$\begin{array}{l}\text { Tillage and } \\
\text { mechanical } \\
\text { weeding }\end{array}$} & Soil structure & Soil compaction increases mortality of germinated seeds \\
\hline & $\begin{array}{l}\text { Soil movements = } \\
\text { f(soil structure) }\end{array}$ & $\begin{array}{l}\text { Seed burial decreases germination and increases pre-emergent } \\
\text { mortality due to insufficient seed reserve. Seeds on soil surface } \\
\text { germinate badly because of insufficient seed-soil contact } \\
\text { Germinated seeds close to soil surface often die because the } \\
\text { top soil dries faster. }\end{array}$ \\
\hline & & $\begin{array}{l}\text { Exposes imbibed seeds to light if inverting tool, thus breaking } \\
\text { dormancy }\end{array}$ \\
\hline & & Triggers germination flush if moist soil \\
\hline & & Destroys germinated seeds, seedlings and plants \\
\hline \multirow[t]{3}{*}{ Crop } & $\begin{array}{l}\text { Choice of cultivation } \\
\text { techniques }\end{array}$ & See effects of techniques \\
\hline & $\begin{array}{l}\text { Occupies space, } \\
\text { uses water and nutrients }\end{array}$ & $\begin{array}{l}\text { Decreases components of weed seed production (plant survival, } \\
\text { tillers/plant, heads/tiller, flowers/head, seeds/flower) }\end{array}$ \\
\hline & & $\begin{array}{l}\text { Seed return to soil seed bank is reduced by crop canopies } \\
\text { in multi-annual crops (e.g. grassland, permanent living mulch) }\end{array}$ \\
\hline \multirow[t]{2}{*}{ Sowing date } & Crop emergence date & $\begin{array}{l}\text { The earlier the weed seedlings emerge relative to the crop, } \\
\text { the better they survive and tiller }\end{array}$ \\
\hline & Date of last tillage & $\begin{array}{l}\text { The later the last tillage, the more weed seeds have germinated } \\
\text { already and are killed by the tillage }\end{array}$ \\
\hline $\begin{array}{l}\text { Sowing } \\
\text { density }\end{array}$ & Crop density & Increases weed seedling mortality \\
\hline \multirow[t]{2}{*}{ Herbicides } & & $\begin{array}{l}\text { Weed mortality = } \mathrm{f} \text { (active ingredient, conditions) } \\
\text { Weed mortality decreases with plant density, seed depth } \\
\text { (for root-acting herbicides) and weed stage }\end{array}$ \\
\hline & & Decreases tillering on surviving plants \\
\hline Mowing & & $\begin{array}{l}\text { Destroys tillers and heads. Plants with mature heads die; } \\
\text { the remaining tiller again but usually produce less seeds }\end{array}$ \\
\hline \multirow[t]{2}{*}{ Nitrogen } & & Increases flowers/head \\
\hline & $\begin{array}{l}\text { Conditions during seed } \\
\text { production }\end{array}$ & $\begin{array}{l}\text { Influence dormancy level and germination rates of newly } \\
\text { produced seeds }\end{array}$ \\
\hline Harvest & & Destruction of all plants \\
\hline
\end{tabular}

Each time plants are destroyed, their seed production, if any, is added to the seed bank. weeds at crop harvest, their seed production, and the seed bank consisting of viable seeds both on surface and buried at different depths in the soil.

\section{The tested cropping systems}

The reference scenario as well as the prospective scenarios were determined by regional experts (Christophe Vivier, Chambre d'Agriculture de I'Yonne; Emmanuel Bonnin, Chambre d'Agriculture de la Nièvre) from their knowledge on local practices and potentials, and then improved step-by-step after analysing the first simulation results, with the aim of reducing operational costs and environmental impacts while maintaining a similar (or lower) weed infestation as in the reference situation. The study covered two French regions, Burgundy and Moselle. Only the results for the former department will be presented here, the latter can be found in Ballot (2009).

The reference scenario consisted in the most frequent rotation observed in the Côte $d^{\prime} \mathrm{Or}$ and Yonne departments, i.e. winter oilseed rape (OSR)/winter wheat/winter barley (Colbach et al., 2009; expert opinion). The crop management for these crops is given in table 2. In a first step, modifications in crop management were tested, mostly concerning tillage, sowing dates and herbicides. These results can be found in previous reports (Ballot, 2009; Colbach, 2009). Here, only the prospective scenarios looking at changes in rotation composition will be presented. These consisted in adding new crops (spring barley, spring or winter pea, sunflower), either by replacing existing crops in the rotation or by inserting them at different locations into the existing rotational pattern. Based on the first simulation results, crop protection programmes were modified step-by-step, trying to reduce herbicide input as much as possible while maintaining a weed infestation similar to the regional reference system.

\section{Simulation plan}

\section{The reference system}

The long-term weed dynamics of the reference system were simulated with ALOMrSYs, starting with an initial blackgrass emergence of 100 plants $/ \mathrm{m}^{2}$ during the first crop season and lasting for 27 years. The system was tested with two different constraints for applying herbicides; these were applied either in optimal or in sub-optimal conditions. The latter would for instance be the case in dairy farms where farmers cannot always spray when hydrothermal conditions are best. Ten repetitions were carried out for each of the two conditions, by randomly choosing each year annual climate scenarios from weather series from 1986 to 
Table 2. Crop management in the oilseed rape/winter wheat/winter barley (OWB) reference cropping system based on expert opinion. The field was ploughed every 6 years before OSR.

\begin{tabular}{|c|c|c|c|c|}
\hline \multirow{2}{*}{$\begin{array}{l}\text { Cultivation } \\
\text { technique }\end{array}$} & \multicolumn{2}{|l|}{ Winter oilseed rape } & \multirow[t]{2}{*}{ Winter wheat } & \multirow[t]{2}{*}{ Winter barley } \\
\hline & Plough & No plough & & \\
\hline $\begin{array}{l}\text { Residues from } \\
\text { previous crop }\end{array}$ & Buried & Buried & Buried & Buried \\
\hline Tillage & $\begin{array}{l}\text { Mouldboard plough ( } 4 \text { July) } \\
\text { Harrow (14 July) } \\
2 \times \text { spring tine (4 Aug., } 19 \text { Aug.) } \\
\text { Harrow ( } 24 \text { Aug.) } \\
\text { Roll (24 Aug.) }\end{array}$ & $\begin{array}{l}\text { Covercrop (14 July) } \\
\text { Chisel ( } 29 \text { July) } \\
\text { Harrow ( } 24 \text { Aug.) } \\
\text { Roll (24 Aug.) }\end{array}$ & $\begin{array}{l}\text { Covercrop ( } 31 \text { July) } \\
\text { Chisel ( } 31 \text { Aug.) } \\
\text { Spring tine ( } 29 \text { Sept.) } \\
\text { Harrow (4 Oct.) }\end{array}$ & $\begin{array}{l}\text { Covercrop (29 July) } \\
\text { Chisel ( } 31 \text { Aug.) } \\
\text { Spring tine ( } 30 \text { Sept.) } \\
\text { Harrow (4 Oct.) }\end{array}$ \\
\hline Sowing date & 24 Aug. & 24 Aug. & 4 Oct. & 4 Oct. \\
\hline $\begin{array}{l}\text { Sowing density } \\
\left(\text { seeds } / \mathrm{m}^{2}\right)\end{array}$ & 50 & 50 & 280 & 300 \\
\hline Herbicides & $\begin{array}{l}\text { Clomazone + dimetachlore } \\
\text { + napropamide }\left(1^{1}, 25 \text { Aug.) }\right. \\
\text { Quizalofop-éthyl isomère } D \\
\text { (1, 18 April) }\end{array}$ & $\begin{array}{l}\text { Glyphosate (0.5, } 14 \text { Aug.) } \\
\text { Clomazone + dimetachlore } \\
\text { + napropamide (1, } 25 \text { Aug.) } \\
\text { Quizalofop-éthyl isomère D } \\
\text { (1,18 April) }\end{array}$ & $\begin{array}{l}\text { lodosulfuron-méthyl-sodium } \\
+ \text { mésosulfuron-méthyl }(0.6,29 \text { Feb. }) \\
\text { Diflufénicanil + ioxynil + bromoxynil } \\
(0.3,29 \text { Feb. }) \\
\text { Florasulame }(0.3,29 \text { Feb. })\end{array}$ & $\begin{array}{l}\text { Chlortoluron (1, } 31 \text { Oct.) } \\
\text { Pendiméthaline + picolinafen } \\
(0.7,31 \text { Oct.) } \\
\text { Fluroxypyr + Florasulam } \\
(0.5,14 \text { April })\end{array}$ \\
\hline $\begin{array}{l}\text { Nitrogen fertiliser } \\
(\mathrm{kg} / \mathrm{ha})\end{array}$ & $\begin{array}{l}70 \text { (1 Feb.) } \\
100 \text { (29 Feb.) }\end{array}$ & $\begin{array}{l}70 \text { (1 Feb.) } \\
100 \text { (29 Feb.) }\end{array}$ & $\begin{array}{l}50 \text { (15 Feb.) } \\
80 \text { (14 March) } \\
50 \text { (29 April) }\end{array}$ & $\begin{array}{l}50 \text { (1 Feb.) } \\
9014 \text { March) }\end{array}$ \\
\hline Harvest date & 14 July & 14 July & 19 July & 29 June \\
\hline
\end{tabular}

Soil texture was $36 \%$ clay, $58 \%$ loam and $6 \%$ sand, with $1 \%$ of stones. Soil depth was $90 \mathrm{~cm}$.

${ }^{1}$ Rates relative to standard rate for active ingredient.

2004 recorded at the meteorological station located at the INRA experimental station at Dijon, France $\left(5^{\circ} 2^{\prime} \mathrm{E}, 47^{\circ} 20^{\prime} \mathrm{N}\right)$. The associated soil climate variables were estimated with the soil-crop model STICS (Brisson et al., 1998b; 2002).

\section{Prospective scenarios}

The same principle was used for prospective scenarios, i.e. each scenario was tested in optimal and sub-optimal spraying conditions, with the same ten climate repetitions that were used for the reference system.

\section{Statistical analyses}

Scenarios were ranked by comparing the medium-term infestation, i.e. the density of mature plants averaged over the rotation, starting with year 13 (see example of figure 1). The latter is the approximate time in the simulation when the infestation did not depend any longer on the infestation level at simulation onset. For each repetition $j \in\{1, \ldots, 10\}$, the medium-term infestations of the scenarios were compared, using the following linear model:

weed density ${ }_{i j k}=$ constant + scenario $_{i}+$ crop $_{k}$

$$
+ \text { error }_{i j k}[1]
$$

with $k \in\{13, \ldots 13+R\}$, with $R=$ rotation length (in years). The scenario ${ }_{i}$ values of each alternative scenario $i$ were then compared to the reference value scenario $_{0}$ and the number of repetitions where the infestation of the alternative scenario exceeded the reference scenario was determined.
The risk of long-term weed progress was analysed with Spearman correlations (PROC CORR Spearman of SAS) between weed densities and

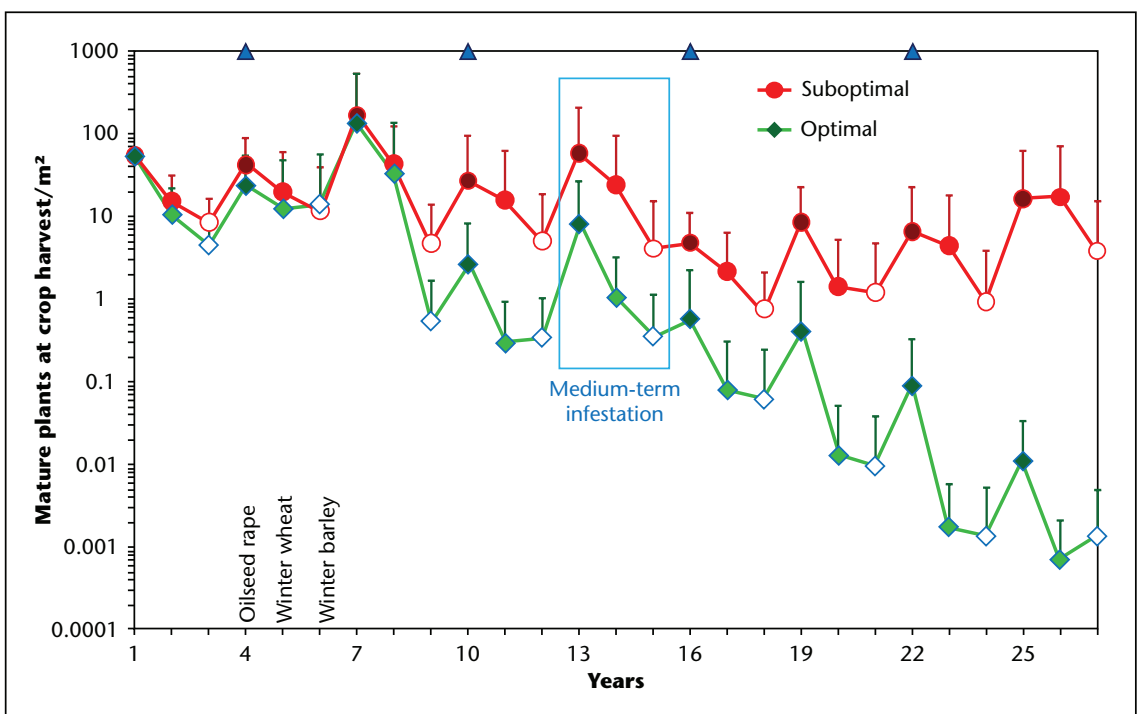

Figure 1. Alopecurus myosuroides dynamics simulated with ALomYSys for the reference cropping system (see table 2 for details) as a function of herbicide treatment conditions. Rotation is winter oilseed rape / winter wheat/winter barley with a mouldboard ploughing every 6 years before oilseed rape (triangles). Means and standard-errors from ten repetitions with randomly chosen weather series from Dijon, Burgundy $\left(5^{\circ} 2^{\prime} \mathrm{E}, 47^{\circ} 20^{\prime} \mathrm{N}\right)$. The rectangle indicates the years over which is calculated the medium-term infestation. 
years 13 to 27 for each scenario and repetition, and the number of repetitions with a significant positive correlation calculated.

\section{Economic evaluation}

For economic calculations, average values over several years were used for costs and prices to cover different contexts and to minimize the impact of yearly variations, thus focusing on rotation composition. The reference yields and operational charges were the average values recorded for the 2004-2008 period (local references of the Agricultural Chambers). The harvest prices were the average of recorded payments over 6 years. Nearly-direct margins were calculated for each crop by multiplying average crop yield and harvest price and substracting average herbicide costs and mechanization costs. Nearly-direct margins were then calculated over the rotation as the average of the individual Nearly-direct margins of each crop of the rotation.

\section{Results}

\section{The reference system}

In the reference cropping systems, simulations showed blackgrass infestation to be usually stable when herbicides were applied in suboptimal conditions, with a medium-term infestation of approximately 30 weeds $/ \mathrm{m}^{2}$ at crop harvest (figure 1). Infestation followed a repetitive pattern, with highest densities in OSR and lowest in winter barley. OSR is very favourable to blackgrass because its early sowing leaves little time for pre-sowing fatal weed seed germination, whether natural or amplified with stale seed bed techniques, to empty the weed seed bank. If preceded by mouldboard ploughing, densities in OSR considerably decreased because ploughing buries most of the weed seeds too deeply for emerging during the cropping season.

Looking only at mean densities can though be misleading because weed dynamics considerably varied between repetitions. Statistical analyses showed that long-term infestation significantly increased in one (figure $2 \mathrm{C}$ ) while it decreased in three out of ten repetitions and was more or less stable in the remaining $60 \%$ of repetitions (results not shown).

When herbicides were always applied in optimal conditions, the same weed density pattern in the rotation was observed (figure 1). Mediumterm infestation was though divided by approximately 10 and there was no long-term risk of density increase (figure 2A). Indeed, when applied in optimal conditions, maximum herbicide efficiency is achieved even when reduced rates are applied as was the case for many herbicides (see example of the reference system, table 2 in the present study).

\section{Changes in rotation}

When herbicides were applied in optimal conditions and the field was ploughed once during the rotation, all the alternative rotations presented a weed level as low or even lower than in the reference system (figure $2 A$ ). In many of the rotations, mean medium-term weed density was negligible though the TFI (treatment frequency index) and the number of herbicide applications were lower than those in the reference system (table 3). When looking at the different rotation types, a few interesting effects can be identified. For instance, replacing winter barley by a spring barley reduced the weed infestation much more than when introducing a spring pea (OWBOWb vs. OWBOWp). As both spring crops were sown at a time when blackgrass seeds are most dormant, a similar reduction in infestation was expected. However, in the present case, herbicide numbers and rates had been reduced much more in the OWBOWp rotation, particularly in the OSR following the spring pea (a 30\% reduction, with a TFI of 1 vs. 1.9 in $R$ and 1.5 in OWBOWb). This was not the case in the OWsW rotation which presented a higher infestation than the similar OWpW rotation (same TFI in OSR in these rotations as in $\mathrm{R}$ ). Here, the reason for the higher infestation was less frequent tillage after the late-harvested sunflower, thus reducing fatal weed seed germination before the next wheat crop. Comparing the OWWp to the OWpW rotation gives the impression that spring crops should best be introduced between successive cereal crops rather than before the high-risk OSR. But again, the reason lies in the herbicide reduction in the OSR of OWWp $(T F I=1)$ rather than in the alternation of crop sowing timings vs. weed seed dormancy cycles. Consequently, placing pea as the preceding crop of OSR is an interesting alternative rotation pattern to reduce chemical applications. This advantage is combined with a lower $\mathrm{N}$ fertilization on OSR and a higher OSR yield (Dumans et al., 2010).

In a second series of simulations, mouldboard ploughing was eliminated, with a simultaneous increase in the TFI and the number of herbicide applications, with a few exceptions (rotations OWpWb, OWsWb, table 3). The various rotations were now more easily discriminated for their weed control (figure $2 B$ ). Five rotations (OWBOWb, OWsW, OWWp, OWBp, OWsWb) presented a medium-term infestation exceeding the reference level in at least 20\% of the repetitions, and one of these rotations $(\mathrm{OWsWb})$ moreover presented a long-term increase in $20 \%$ of the repetitions. Though blackgrass emerges and reproduces less well in spring and summer crops than in winter crops, this reduction was not sufficient in the absence of the beneficial ploughing effect to compensate for the reduction in herbicide rates and frequencies, particularly when these were carried out in the high-risk OSR crops. The elimination of mouldboard ploughing was less detrimental when the frequency of OSR in the rotation was decreased (e.g. OWBpWB, OWsWpW, OWWsWp,OWbsBp).

In the third series of simulations (figure $2 \mathrm{C}$ ), the fields were again ploughed at least once during the rotation when herbicides were applied in sub-optimal conditions. The resulting loss in herbicide efficiency did not always lead to an infestation increase. The most risky cases were those with a high OSR frequency in the rotation (i.e. R, OWBOWb, OWBOWp, OWsW) and/or a decrease in number of tillage operations (e.g. OWBsWB, OWsW, OWsWB, $\mathrm{OWsWb}$ ), the latter resulting in a decrease in fatal pre-sowing weed seed germination. Again, the effect of the sub-optimal spraying conditions was less detrimental when the OSR frequency in the rotation was low.

If, moreover, ploughing was eliminated from the cropping systems, weed infestation increased even more (figure 2D). The sole exceptions were those with a low OSR frequency and at least one spring pea in the rotation (i.e. OWBpWB, OWpWB, OWsWpW, OWWsWp). This was though not true if the TFI was reduced too much, particularly in the high-risk OSR (i.e. OWpWb, OWBsBp).

When comparing similar rotation patterns, spring pea appeared to be more weedsuppressive than either winter pea or sunflower (e.g. OWpW vs. OWPW, OWpWB and OWpWb vs. OWsWB and OWsWb in figure 2D). Indeed, winter pea is sown at a time when the weed seeds are not yet fully dormant whereas sunflower is harvested late enough that even spring-emerging blackgrass plants have time to reproduce. It is though difficult to separate this effect from management effects. For instance, herbicide rates were lower and tillage operations more numerous in winter pea vs. spring pea while herbicide numbers, rates and efficiencies were higher in sunflower vs. spring pea but tillage operations less frequent after sunflower than after spring pea.

\section{Economic evaluation}

The reference system and the five first prospective scenarios (with occasional mouldboard ploughing) were evaluating, calculating input and operational costs as well as the economic margin per ha (table 4). All except the OWBOWb system presented lower weed 


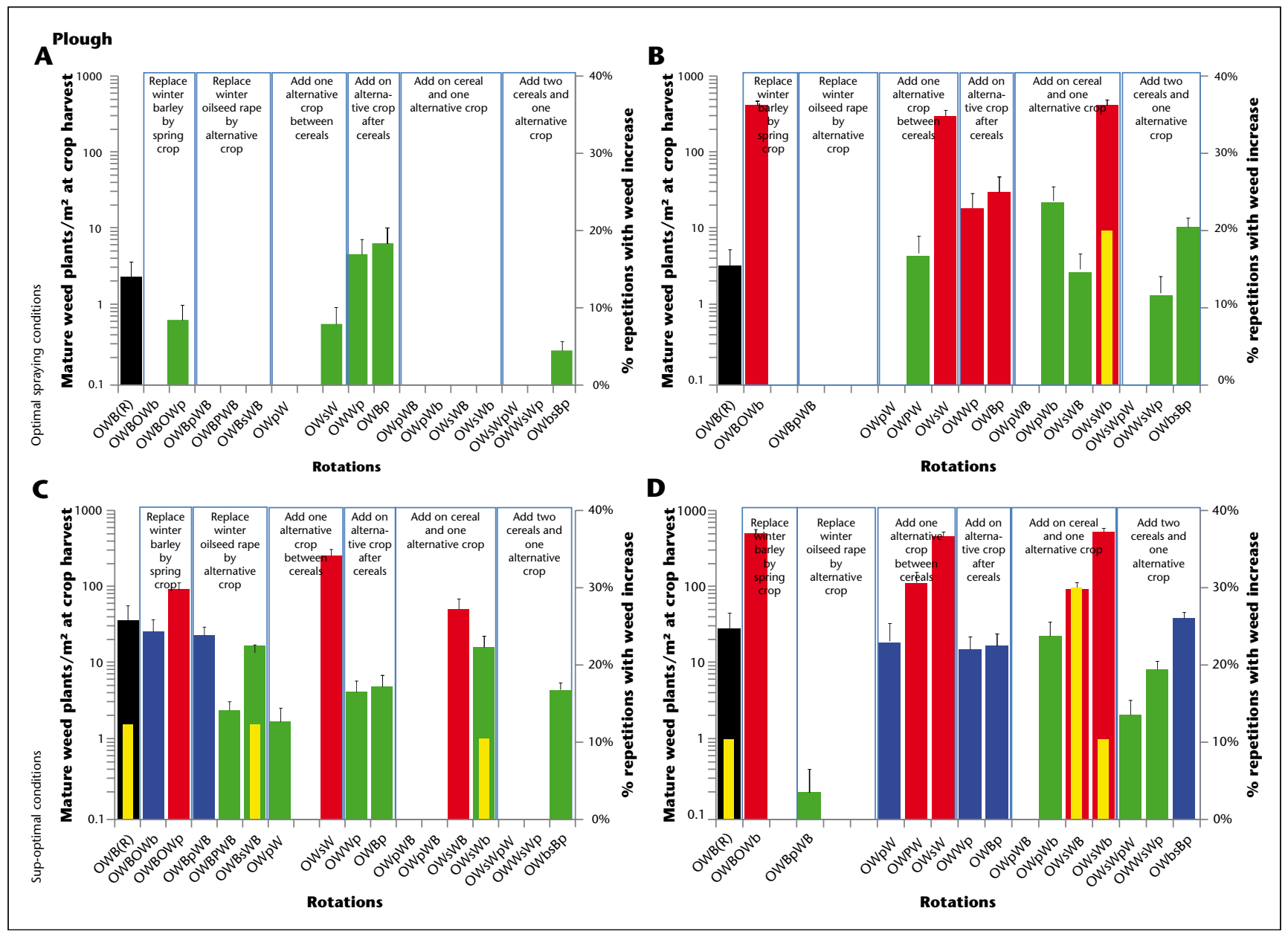

Figure 2. Evaluation of prospective rotations (see table 3 for details) for grass weed control with ALomySys as a function of herbicide treatment conditions and primary tillage. Each scenario was simulated 10 times with randomly chosen climate series from Dijon, Burgundy. The left-hand axis shows the medium-term weed infestation, distinguishing the reference system (black bars) and prospective scenarios (green, blue and red bars indicating whether 0\%, 10\% or >10\% of repetitions with infestation > reference). The right-hand axis indicates the risk of long-term weed increase (yellow bars).

control costs, and all except the OWBsWB system obtained higher returns than the reference system. The two systems with the best economic results were those where OSR was replaced by either spring or winter pea $(+19 €$ per ha and year for OWBPWB, $+17 €$ for OWBPWB) instead of spring barley or sunflower. These improved results were mostly due to lower herbicide costs. The rotations with spring pea also presented lower mechanization costs because of reduced tillage. The other interesting case was the one where OSR was preceded by spring pea once every six years $(+10 €$ per ha and year for OWBOWp).

\section{Discussion}

\section{Modelling approach}

Models have the big advantage of being able to test a large range of situations at long term, which is difficult and expensive in field experi- ments. The present modelling approach was based on a process-based representation of effects of techniques and their interactions with environmental conditions. This is interesting compared with heavy and costly experimentations with rotations at long term in real life. This approach was preferred to synthetic observations from field trials because cultivation techniques have complex and sometimes compensating effects (e.g. seedling mortality vs. triggering of seed germination by tillage) that interact with environmental conditions and weed stages. Moreover, the modular structure of ALomySys makes possible the independent and successive improvement and addition of submodels (Colbach et al., 2006b; 2007; 2010).

The disadvantage of this approach is the high number of required condition-specific relationships, often established in controlled and sometimes artificial conditions. Moreover, it is not possible to evaluate in advance how the model built from the various components will exactly behave in field conditions. It is therefore essential to compare model simulations with independent field observations. This has already been carried out for a large part of ALomyYs (Colbach et al., 2006a; 2007). The model was shown to produce satisfactory predictions except in case of zero tillage. However, the model has not been evaluated in all possible situations, e.g. organic farming or summer crops (among which sunflower). Comparisons with literature though showed the simulations to be consistent with field observations (e.g. Kurstjens \& Kropff, 2001; Meiss et al., 2008; Chikowo et al., 2009 for mechanical weeding and grassland).

\section{Implications for management strategies}

The present simulation study evaluated a large range of rotations adapted to the region of Burgundy and demonstrated the major advan- 
Table 3. Reference cropping system and prospective scenarios proposed by experts and tested with ALomyYs for their effects on weed dynamics.

\begin{tabular}{|c|c|c|c|c|c|c|c|c|}
\hline \multirow[t]{3}{*}{ Rotation ${ }^{1}$} & \multirow[t]{3}{*}{ Scenario } & \multicolumn{3}{|c|}{$\begin{array}{l}\text { Number of tillage operations } \\
\text { (mean per year over rotation) }\end{array}$} & \multicolumn{4}{|c|}{$\begin{array}{l}\text { Herbicides } \\
\text { (mean per year over rotation) }\end{array}$} \\
\hline & & \multirow{2}{*}{$\begin{array}{l}\text { Mouldboard } \\
\text { ploughing }\end{array}$} & \multirow[t]{2}{*}{ Roll } & \multirow{2}{*}{$\begin{array}{l}\text { Other } \\
\text { tools }\end{array}$} & \multirow[t]{2}{*}{$\overline{\text { TFI }^{2}}$} & \multirow{2}{*}{$\begin{array}{l}\text { Cumulated } \\
\text { efficiency }(\%)^{3}\end{array}$} & \multicolumn{2}{|c|}{ Number in } \\
\hline & & & & & & & Autumn & Spring \\
\hline \multicolumn{9}{|c|}{ Reference system } \\
\hline OWB & $\mathrm{R}$ & 0.17 & 0.33 & 3.83 & 1.88 & 2.43 & 1.50 & 1.33 \\
\hline \multicolumn{9}{|c|}{ Replacing winter barley by spring crop } \\
\hline \multirow[t]{2}{*}{ OWBOWb } & $P$ & 0.17 & 0.50 & 3.83 & 1.48 & 1.97 & 1.00 & 1.33 \\
\hline & $\mathrm{NP}$ & 0.00 & 0.50 & 3.83 & 1.77 & 2.30 & 1.17 & 1.50 \\
\hline \multirow[t]{2}{*}{ OWBOWp } & $P$ & 0.17 & 0.50 & 3.67 & 1.13 & 1.94 & 1.00 & 1.33 \\
\hline & $\mathrm{NP}$ & Not tested & & & & & & \\
\hline \multicolumn{9}{|c|}{ Replacing winter oilseed rape by alternative crop } \\
\hline \multirow[t]{2}{*}{ OWBpWB } & $P$ & 0.17 & 0.33 & 3.83 & 1.27 & 2.24 & 1.17 & 1.50 \\
\hline & NP & 0.00 & 0.33 & 3.83 & 1.78 & 2.41 & 1.17 & 1.67 \\
\hline \multirow[t]{2}{*}{ OWBPWB } & $P$ & 0.17 & 0.17 & 4.17 & 1.23 & 2.08 & 1.00 & 1.67 \\
\hline & NP & Not tested & & & & & & \\
\hline \multirow[t]{2}{*}{ OWBsWB } & $P$ & 0.17 & 0.33 & 3.67 & 1.35 & 2.08 & 1.17 & 1.33 \\
\hline & NP & Not tested & & & & & & \\
\hline \multicolumn{9}{|c|}{ Adding one alternative crop between cereals } \\
\hline \multirow[t]{2}{*}{ OWpW } & P & 0.25 & 0.50 & 4.00 & 1.40 & 1.96 & 0.75 & 1.75 \\
\hline & NP & 0.00 & 0.50 & 4.00 & 1.58 & 2.21 & 0.75 & 2.00 \\
\hline \multirow[t]{2}{*}{ OWPW } & $P$ & Not tested & & & & & & \\
\hline & NP & 0.00 & 0.25 & 4.25 & 1.30 & 1.96 & 0.75 & 2.00 \\
\hline \multirow[t]{2}{*}{ OWsW } & P & 0.25 & 0.50 & 3.50 & 1.38 & 1.71 & 0.75 & 1.50 \\
\hline & NP & 0.00 & 0.50 & 3.50 & 1.55 & 1.96 & 0.75 & 1.75 \\
\hline \multicolumn{9}{|c|}{ Adding one alternative crop after cereals } \\
\hline \multirow[t]{2}{*}{ OWWp } & $P$ & 0.25 & 0.50 & 3.75 & 1.38 & 1.91 & 0.75 & 1.50 \\
\hline & NP & 0.00 & 0.50 & 3.75 & 1.55 & 2.16 & 0.75 & 1.75 \\
\hline \multirow[t]{2}{*}{ OWBp } & $P$ & 0.25 & 0.50 & 3.50 & 1.28 & 1.66 & 0.75 & 1.25 \\
\hline & NP & 0.00 & 0.50 & 3.50 & 1.45 & 1.91 & 0.75 & 1.50 \\
\hline \multicolumn{9}{|c|}{ Adding one cereal and one alternative crop } \\
\hline OWpWB & $P$ & 0.20 & 0.40 & 3.80 & 1.54 & 2.13 & 1.00 & 1.60 \\
\hline & NP & 0.00 & 0.40 & 3.80 & 1.68 & 2.33 & 1.00 & 1.80 \\
\hline OWpWb & $P$ & 0.40 & 0.60 & 4.00 & 1.32 & 1.77 & 0.40 & 1.80 \\
\hline & NP & 0.00 & 0.60 & 4.00 & 1.20 & 1.56 & 0.40 & 1.60 \\
\hline OWsWB & $P$ & 0.20 & 0.40 & 3.40 & 1.44 & 1.73 & 1.00 & 1.20 \\
\hline & NP & 0.00 & 0.40 & 3.40 & 1.58 & 1.93 & 1.00 & 1.40 \\
\hline OWsWb & $P$ & 0.40 & 0.60 & 3.60 & 1.44 & 1.77 & 0.40 & 1.80 \\
\hline
\end{tabular}




\begin{tabular}{|c|c|c|c|c|c|c|c|c|}
\hline \multirow[t]{3}{*}{ Rotation ${ }^{1}$} & \multirow[t]{3}{*}{ Scenario } & \multicolumn{3}{|c|}{$\begin{array}{l}\text { Number of tillage operations } \\
\text { (mean per year over rotation) }\end{array}$} & \multicolumn{4}{|c|}{$\begin{array}{l}\text { Herbicides } \\
\text { (mean per year over rotation) }\end{array}$} \\
\hline & & \multirow{2}{*}{$\begin{array}{l}\text { Mouldboard } \\
\text { ploughing }\end{array}$} & \multirow[t]{2}{*}{ Roll } & \multirow{2}{*}{$\begin{array}{l}\text { Other } \\
\text { tools }\end{array}$} & \multirow[t]{2}{*}{$\mathrm{TFI}^{2}$} & \multirow{2}{*}{$\begin{array}{l}\text { Cumulated } \\
\text { efficiency }(\%)^{3}\end{array}$} & \multicolumn{2}{|c|}{ Number in } \\
\hline & & & & & & & Autumn & Spring \\
\hline & NP & 0.00 & 0.60 & 3.60 & 1.18 & 1.36 & 0.40 & 1.40 \\
\hline \multicolumn{9}{|c|}{ Adding two cereals and one alternative crop } \\
\hline \multirow[t]{2}{*}{ OWsWpW } & $P$ & 0.40 & 0.60 & 3.60 & 1.14 & 1.34 & 0.40 & 1.40 \\
\hline & NP & 0.00 & 0.60 & 3.60 & 1.42 & 1.74 & 0.40 & 1.80 \\
\hline \multirow[t]{2}{*}{ OWWsWp } & $P$ & 0.40 & 0.60 & 3.80 & 1.30 & 1.70 & 0.60 & 1.40 \\
\hline & NP & 0.00 & 0.60 & 3.80 & 1.58 & 2.10 & 0.60 & 1.80 \\
\hline \multirow[t]{2}{*}{ OWBsBp } & $P$ & 0.33 & 0.50 & 3.33 & 1.07 & 1.25 & 0.50 & 1.17 \\
\hline & NP & 0.00 & 0.50 & 3.33 & 1.30 & 1.58 & 0.50 & 1.50 \\
\hline
\end{tabular}

${ }^{1} \mathrm{O}=$ oilseed rape, $\mathrm{W}=$ wheat, $\mathrm{B}=$ barley, $\mathrm{P}=$ pea, $\mathrm{s}=$ sunflower; uppercase letters indicate winter crops, lowercase letters spring and summer crops; the latter were always preceded by temporary ("catch") crops not indicated in the table.

${ }^{2}$ The annual treatment frequency index (TFI) is the sum of all herbicide rates relative to the standard rate and relative to the whole field area (e.g. the TFI for the four management strategies of table 1 are 2, 2.5, 1.2 and 2.2, respectively).

${ }^{3}$ Cumulated efficiency per year is the sum of all theoretical herbicide efficiencies at full rate (which corresponds to the actual efficiency in case of optimal spraying conditions).

Table 4. Input and operational costs as well as margin of selected cropping systems with occasional mouldboard ploughing from the Burgundy case study (adapted from Ballot, 2009).

\begin{tabular}{|c|c|c|c|c|c|c|}
\hline \multirow[t]{2}{*}{ Cropping system scenarios } & \multicolumn{4}{|c|}{ Costs $\left(€ h a^{-1}\right.$ year $\left.^{-1}\right)$} & \multirow{2}{*}{\multicolumn{2}{|c|}{$\begin{array}{l}\text { Nearly-direct margin } \\
\left(€ \mathrm{ha}^{-1} \text { year }^{-1}\right)\end{array}$}} \\
\hline & \multirow{2}{*}{$\begin{array}{l}\text { Herbicides } \\
76\end{array}$} & \multirow{2}{*}{$\begin{array}{l}\text { Mechanization } \\
262\end{array}$} & \multicolumn{2}{|c|}{ Total weed control } & & \\
\hline Reference system OWB & & & 338 & & 286 & \\
\hline OWBOWb & 82 & 258 & 340 & $(+1 \%)$ & 296 & $(+3 \%)$ \\
\hline OWBOWp & 67 & 253 & 320 & $(-5 \%)$ & 289 & $(+1 \%)$ \\
\hline OWBpWB & 64 & 256 & 320 & $(-5 \%)$ & 305 & $(+7 \%)$ \\
\hline OWBPWB & 59 & 264 & 323 & $(-4 \%)$ & 303 & $(+6 \%)$ \\
\hline OWBsWB & 65 & 254 & 319 & $(-6 \%)$ & 278 & $(-3 \%)$ \\
\hline
\end{tabular}

Values in brackets are variations relative to the reference system. Nearly-direct margins were calculated for each crop by multiplying average crop yield and harvest price and substracting average herbicide costs and mechanization costs. Nearly-direct margins were then calculated over the rotation as the average of the individual nearlydirect margins of each crop of the rotation.

tage of diversifying rotations for weed control. The more diverse the rotation, the better the studied grass weed was controlled and the less herbicides (rates and frequencies) were necessary. The latter is good news from an environmental point of view even if further evaluation is required for assessing actual toxicity levels. It should also facilitate work organization for the farmer, but again, this advantage needs to be checked with additional agronomic and socio-economic analyses. Moreover, diverse rotations were less susceptible to spraying conditions, thus reducing another constraint in farm work organization. Similarly, mouldboard ploughing was less essential in diverse rotations, thus again facilitating work organization and limiting adverse effects on the environment (e.g. less soil erosion, less impact on soil fauna). Conversely, rotations with occasional ploughing make rotations less susceptible to spraying conditions, thus reducing the production variability. Another major advantage of diverse rotations was not evaluated here, i.e. the possibility of alternating active ingredients with different modes of action, thus considerably reducing the risk of selecting herbicideresistant weed populations (Délye, 2005).

The diversification of the rotation must though be well reasoned. When replacing a high-risk crop (here winter crops) by a low-risk crop (here spring crops), it is better to eliminate those crops that most favour the dominant weed. Usually, favourable crops are those that are sown when weed seeds are least dormant (Fried et al., 2008; Fried et al., 2009), in the present case winter cereals. Our simulations though showed OSR to be the riskiest crop because of insufficient time for stale seed bed techniques. Similarly, low-risk crops must not only be sown when weed seeds are most dormant (i.e. spring and summer crops) but also leave enough time after harvest for sufficient germination-triggering tillage, thus excluding many summer crops.

The judicious choice of cultural practices is not limited to mouldboard ploughing and stale seed bed techniques. Several simulations demonstrated the danger of reducing herbicide rates in high-risk crops (e.g. OSR), even when preceded by a low-risk crop (e.g. spring pea). 
Herbicide programs need to be reasoned taking account of the whole rotation and not only of the immediately preceding crop. Thus, FTI can be reduced to very low levels, even in high-risk crops, when the frequency of the latter is low in the rotation and/or when additional cultural measures (e.g. delayed sowing, mouldboard ploughing) limit the weed risk.

Diversified rotations were not only more robust from a weed control point of view, they also often produced equivalent or better economic results than the usual reference system when evaluated over the whole rotation length (instead of analysing individual annual crop benefits). Thus, the economic comparison of the 6-year rotations highlighted the interest of (spring or winter) pea either replacing or preceding OSR in the reference system of OWBOWB. Similar trends (i.e. larger benefits in diversified rotations, particularly with pea) were observed in another French regional case study (Moselle) (Ballot, 2009; Tiers et al., 2010).

\section{Need for future research}

The simulated efficiency of rotations and cultivation techniques could probably be improved if crop management was not considered as a fixed programme where operations are always carried out at the same date, irrespective of weather or soil conditions. If decision-rule models (Bergez et al., 2002; Keating et al., 2003; Chatelin et al., 2005) could be connected to ALomySYs to take account of practical guidelines (depending on weather, soil moisture and crop and weed growth stage) and trafficability restrictions, simulations would be more robust and used to improve guidelines, to assess risks and associated costs.

Moreover, the present study focused on a single particular weed species, i.e. blackgrass, and the results and guidelines are only valid for similar species types (autumn-emerging, spring dormancy, susceptibility to stale seed bed techniques, no emergence for deeply buried seeds, seeds only surviving a few years, etc.) such as Bromus tectorum (Blackshaw, 1993) or Vulpia myuros (Ball et al., 2008). General guidelines could also be extrapolated, based on the underlying biological processes. For instance, to control spring-emerging weeds, reduce the frequency of spring crops in the rotation. The present results were thus presented to experts who thought the tested ajustements in the crop protection programmes to be adequate also for other major weeds. However, such advice is vague, does not quantify the differences between rotations or evaluate the variability in effects. Consequently, we are presently working on extrapolating the ALOMYSYs model to a multi-specific weed flora (Gardarin et al., 2010; Gardarin, 2008).

\section{Conclusion}

The present simulation study demonstrated the advantage of using weed dynamics models to evaluate prospective rotations for integrated weed control at medium and long-term and to identify the most promising changes in the rotation patterns as well as the underlying processes. The simulations showed the necessity for reasoning herbicide programs over the whole rotation and not simply as function of the preceding crop as well as the key role of tillage. The present case study demonstrated the advantage of integrating the agronomic effects of the crop rotation composition into the competitiveness indicators of cropping systems, highlighting the economic value of diversification crops (such as pea), especially in systems based on cereals and oil seed crops. The present study needs to be completed by looking at additional improvements of cropping systems, such as reducing nitrogen fertilization, and at additional criteria evaluating the environmental impacts of the tested rotations such as pesticide toxicity or greenhouse gas emissions.

Acknowledgements. The present work was financed by INRA, ANR OGM VIGIWEED (ANR-07-POGM-003-01) and ANR SYSTERRA ADVHERB (ANR-08-STRA-02), by ONIDOL and UNIP, and by the French Ministry of Agriculture and Fisheries (Casdar AAP 7175).

\section{REFERENCES}

Aubertot JN, Lescourret F, Bonato O, Colbach N, Debaeke P, Doré T, Fargues ], Lô-Pelzer E, Loyce C, Sauphanor B. How to improve pest management in cropping systems. Effects of cultural practices on pest development. A review. Agronomy for Sustainable Development.

Ball DA, Frost SM, Fandrich L, Tarasoff C, MallorySmith C. Biological Attributes of Rattail Fescue (Vulpia myuros). Weed Science 2008; 56: 26-31.

Ballot R. Prise en compte des facteurs agronomiques dans les indicateurs de rentabilité des successions culturales. Mémoire de fin d'études d'ingénieur, ESA, Angers, 2009, 135 p.

Bergez JE, Deumier JM, Lacroix B, Leroy P, Wallach D. Improving irrigation schedules by using a biophysical and a decisional model. Eur / Agronom 2002; 16: 123-35.

Blackshaw RE. Downy brome (Bromus tectorum) density and relative-time of emergence affects interference in winter wheat (Triticum aestivum). Weed Science 1993; 41: 551-6.
Brisson N, Mary B, Ripoche D, et al. STICS: a generic model for the simulation of crops and their water and nitrogen balances. I. Theory and parameterization applied to wheat and corn. Agronomie 1998a; 18: 311-46.

Brisson N, Mary B, Ripoche D, et al. STICS: a generic model for the simulation of crops and their water and nitrogen balances. I. Theory and parameterization applied to wheat and corn. Agronomie 1998b; 18: 311-46.

Brisson N, Ruget F, Gate PJL, et al. STICS: a generic model for simulating crops and their water and nitrogen balances. II. Model validation for wheat and maize. Agronomie 2002; 22: 69-92.

Chatelin MH, Aubry C, Poussin JC, et al. DéciBlé, a software package for wheat crop management simulation. Agricultural Systems 2005; 83: 77-99.

Chauvel B, Guillemin JP, Colbach N, Gasquez J. Evaluation of cropping systems for management of herbicide-resistant populations of blackgrass (Alopecurus myosuroides Huds.). Crop Protection 2001; 20: 127-37.

Chikowo R, Faloya V, Petit S, Munier-Jolain N. Integrated Weed Management systems allow reduced reliance on herbicides and long term weed control. Agriculture, Ecosystems and Environment 2009 (In press).

Colbach N, Debaeke P. Integrating crop management and crop rotation effects into models of weed population dynamics: a review. Weed Science 1998; 46: 717-28.

Colbach N, Dürr C, Roger-Estrade J, Caneill J. How to model the effects of farming practices on weed emergence. Weed Research 2005; 45: 2-17.

Colbach N, Busset H, Yamada O, Dürr C, Caneill J. ALOMYSYS: modelling black-grass (Alopecurus myosuroides Huds.) germination and emergence, in interaction with seed characteristics, tillage and soil climate. II. Evaluation. Eur J Agronom 2006a; 24: 113-28.

Colbach N, Dürr C, Roger-Estrade J, Chauvel B, Caneill J. ALOMYSYS: modelling blackgrass (Alopecurus myosuroides Huds.) germination and emergence, in interaction with seed characteristics, tillage and soil climate. I. Construction. Eur J Agronom 2006b; 24: 95-112.

Colbach N, Chauvel B, Gauvrit C, Munier-Jolain NM. Construction and evaluation of ALOMYSYS, modelling the effects of cropping systems on the blackgrass life-cycle. From seedling to seed production. Ecological Modelling 2007; 201: 283-300.

Colbach N, Sassi A, Granger S. ALOMYSYS: a model for evaluating and developing cropping systems for integrated weed management. In: 10th congress of the European Society for Agronomy, Bologne (Italie), 2008.

Colbach N. Évaluation de systèmes de culture régionaux et tests de scénarios prospectifs réduisant herbicides et travail du sol. INRA, 2009, 17 p. 
Colbach N, Granger S, Munier-Jolain NM. Using weed dynamics models for evaluating and developing integrated cropping systems. In: XIII Colloque international sur la biologie des mauvaises herbes, Dijon, France, 2009.

Colbach N, Kurstjens DAG, Munier-Jolain NM, Dulout-Dalbiès A, Doré T. Assessing non-chemical weeding strategies through a modelling approach applied to blackgrass (Alopecurus myosuroides Huds.) dynamics. Eur J Agron 2010; 32: 205-18.

Colbach N. Modelling cropping system effects on crop pest dynamics: how to compromise between process analysis and decision aid. Plant Science 2010; 179: 1-13.

Délye C. Weed resistance to acetyl coenzyme A carboxylase inhibitors: an update. Weed Science 2005; 53: 728-46.

Délye C, Menchari Y, Guillemin JP, et al. Status of blackgrass (Alopecurus myosuroides) resistance to acetyl-coenzyme A carboxylase inhibitors in France. Weed Research 2007; 47: 95-105.

Doyle C], Cousens R, Moss SR. A model of the economics of controlling Alopecurus myosuroides Huds. in winter wheat. Crop Protection 1986; 5: 143-50.

Dumans $P$, Flénet $F$, Wagner $D$, Bonnin E, Schneider A. Prise en compte des effets précédents dans la rentabilité des cultures - Pour gagner plus avec du colza, placez-le après pois! Perspectives Agricoles 2010; 268: 4-8.
Fried G, Norton LR, Reboud X. Environmental and management factors determining weed species composition and diversity in France. Agriculture, Ecosystems \& Environment 2008; 128: 68-76.

Fried G, Chauvel B, Reboud X. A functional analysis of large-scale temporal shifts from 1970 to 2000 in weed assemblages of sunflower crops in France. Journal of Vegetation Science 2009; 20: 49-58.

Gardarin A, Dürr C, Colbach N. Effects of seed depth and soil structure on the emergence of weeds with contrasted seed traits. Weed Research 2010; 50: 91-101.

Gardarin A. Modélisation des effets des systèmes de culture sur la levée des advnetices à partir de relations fonctionnelles utilisant les traits des espèces. PhD Thesis, Université de Bourgogne, Dijon, France, 2008, 280 p.

Gasquez J. État de la résistance aux herbicides en France. In: Proceedings of Xème Colloque International sur la Biologie des Mauvaises Herbes. Dijon, France, (1996) 173-180

Keating BA. Carberry PS, Hammer GL, Probert ME, Robertson MJ, Holzworth D, Huth N I, Hargreaves JNG, Meinke H, Hochman Z, McLean G, Verburg K, Snow V, Dimes JP, Silburn M, Wang E, Brown $S$, Bristow KL, Asseng S, Chapman S, McCown RL, Freebairn DM, Smith CJ. An overview of APSIM, a model designed for farming systems simulation. Eur J Agronom 2003; 18: 267-88.
Kurstjens DAG, Kropff MJ. The impact of uprooting and soil-covering on the effectiveness of weed harrowing. Weed Research 2001; 41: 211-28.

Meiss H, Munier-Jolain N, Henriot F, Caneill J. Effects of biomass, age and functional traits on regrowth of arable weeds after cutting. Journal of Plant Diseases and Protection 2008: 493-9.

Moss SR. Herbicide resistance in black-grass (Alopecurus myosuroides Huds.). In: Proceedings of Proceedings 1987 British Crop Protection Conference-Weeds Brighton, England, 1987; 879-86

Munier-Jolain NM, Chauvel B, Gasquez J. Long-term modelling of weed control strategies: analysis of threshold-based options for weed species with contrasted competitive abilities. Weed Research 2002; 42: 107-22.

Rossing WAH, Meynard JM. van I MK. Model-based explorations to support development of sustainable systems: case studies from France and the Netherlands. Eur J Agronom 1997; 7: 271-83.

Tiers N., Schneider A, Ballot R. Le pois dans la rotation - une culture altruiste. Cultivar 2010; Février: 32-4.

Van Himme M, Bulcke R. Distribution, extension et importance d'Alopecurus myosuroides Huds. en Europe. In: Proceedings of Proceedings European Weed Research Society Symposium Status, Biology and control of grassweeds in Europe, 1975): 23-54 